\title{
PERSEPSI MAHASISWA TERHADAP PEMBELAJARAN JARAK JAUH PADA MATA KULIAH DRAINASE PERKOTAAN PROGRAM STUDI PENDIDIKAN TEKNIK BANGUNAN
}

\author{
Prisma Ceila Perdana ${ }^{1}$, Arris Maulana ${ }^{2}$, dan R. Eka Murtinugraha ${ }^{3}$ \\ ${ }_{1,2,3}$ Pendidikan Teknik Bangunan, FT, UNJ \\ Email: prismaceila89@gmail.com
}

\begin{abstract}
ABSTRAK
Penelitian ini bertujuan untuk mengetahui persepsi mahasiswa serta kendala pembelajaran jarak jauh pada mata kuliah Drainase Perkotaan Prodi Pendidikan Teknik Bangunan. Penelitian ini merupakan penelitian deskriptif kuantitatif. Populasi penelitian adalah mahasiswa Pendidikan Teknik Bangunan angkatan 2016 dan 2017 yang mengambil mata kuliah Drainase Perkotaan pada semester genap tahun akademik 2019/2020 dengan sampel penelitian berjumlah 47 mahasiswa. Hasil penelitian menunjukan bahwa persepsi mahasiswa terhadap pembelajaran jarak jauh Drainase Perkotaan cukup baik. Pengorganisasian materi serta pengunaan media, metode serta platform yang digunakan telah sesuai dengan tujuan pembelajaran meskipun pembelajaran belum sistematis. Mahasiswa telah memiliki fasilitas serta pengetahuan tentang pembelajaran jarak jauh sehingga tingkat pembelajaran telah sesuai. Pendidik telah memberikan sikap positif berupa kesempatan bertanya dan memberikan umpan balik terhadap tugas yang diberikan namun pembelajaran jarak jauh tidak meningkatkan motivasi mahasiswa. Pengalokasian waktu dalam pembelajaran sudah cukup baik dalam pembelajaran maupun dalam mengerjakan tugas. Kendala dalam PJJ Drainase Perkotaan adalah kurangnya interaksi dalam pembelajaran, sinyal yang kurang mendukung dalam mengakses pembelajaran, kurangnya pemahaman materi serta diperlukannya variasi media dalam pembelajaran..
\end{abstract}

Kata kunci: Persepsi, Pembelajaran Jarak Jauh, Drainase Perkotaan

\section{ABSTRACT}

This study aims to find out the perception of students as well as the constraints of distance learning in Urban Drainage course of the Building Engineering Education Educational Program. This research is quantitative descriptive. The research population is students of Building Engineering Education class 2016 and 2017 who took Urban Drainage courses in the even semester of academic year 2019/2020 with a research sample of 47 students. The results showed that students perception of urban drainage distance learning is quite good. The organizing of materials and the use of media, methods and platforms used are in accordance with the objectives of learning has not been systematic. Students already have facilities and knowledge about distance learning so that the level of learning is appropriate. Educators have given positive attitudes in the form of opportunities to ask questions and give feedback on assignments given but distance learning does not increase student motivation. Allocating time in learning is enough both in learning and in doing tasks. Obstacles in distance learning in Urban Drainage are lack of interaction in learning, less supportive signals in accessing learning, lack of material understanding and the need for media variation in learning.

Keywords: Perception, Distance Learning, Urban Drainage

\section{PENDAHULUAN}

Berkembangnya teknologi informasi dan komunikasi semakin mempermudah kebutuhan manusia dalam berbagai bidang pekerjaan salah satunya dalam bidang pendidikan khususnya pada masa menghadapi pandemi Virus Corona atau
COVID-19. COVID-19 (Corona Virus Disease). Implikasi COVID-19 membuat pembelajaran bergeser dari pembelajaran tatap muka menjadi dilakukan melalui dunia maya baik tatap muka maupun non tatap muka (Bustomi, 2020: 1017).

Berdasarkan surat edaran Kementrian Pendidikan dan Kebudayaan 
(Kemendikbud) Direktorat Pendidikan Tinggi No. 1 tahun 2020 tentang pencegahan penyebaran COVID-19 di perguruan tinggi memberikan himbauan kepada perguruan tinggi untuk menyelenggarakan Pembelajaran Jarak Jauh (PJJ). Melalui Surat Edaran Rektor UNJ Nomor 7/UN39/SE/2020 tentang Upaya Peningkatan Kewaspadaan dan Pencegahan terhadap Penyebaran COVID-19 di lingkungan Universitas Negeri Jakarta (UNJ) dan Labschool serta Surat Edaran Rektor UNJ Nomor 12/UN39/SE/2020 tentang perpanjangan Masa PJJ dan Work From Homes (WFH).

Pembelajaran Jarak Jauh pada Program Studi Pendidikan Teknik Bangunan (PTB) merupakan sistem pembelajaran yang baru, sebelumnya pembelajaran dilakukan secara tatap muka. Pada Program Studi PTB terdapat mata kuliah Drainase Perkotaan, Mata kuliah ini merupakan salah satu mata kuliah wajib Program Studi PTB. Pemahaman dan minat mempelajari mata kuliah ini sangat diperlukan agar lulusan dapat memiliki wawasan dan keahlian dalam merencanakan sistem drainase yang dapat berguna didalam dunia teknik sipil. Peneliti melakukan survey pendahuluan terhadap 26 mahasiswa yang menempuh mata kuliah Drainase Perkotaan semester genap tahun akademik 2019/2020 pembelajaran, persepsi pada awal pembelajaran kurang baik. Persepsi akan mempengaruhi hasil belajar setiap individu karena persepsi merupakan kecenderungan seseorang terhadap sesuatu (Nugraha, 2015: 3). Didapatkan hasil bahwa media yang digunakan dalam pembelajaran menggunakan e-modul dengan sistem PJJ menggunakan aplikasi Google Classroom, Group Whatsapp dan Zoom. Adapun hanya sebesar 7,7 \% mahasiswa yang paham dengan materi yang disampaikan dalam pembelajaran mata kuliah drainase perkotaan sedangkan 92,3\% masuk kategori cukup paham hingga sangat tidak paham. Serta hanya sebesar 19,2\% mahasiswa yang merasa puas dengan materi PJJ drainase perkotaan, sisanya 3 sebesar 80,8\% kurang merasa puas terhadap materi PJJ. Sebesar $53,8 \%$ mahasiswa juga mengatakan kurangnya waktu dalam pembelajaran. Hal ini bertentangan dengan pernyataan Firman \& Rahman (2020: 84) bahwa pembelajaran online memiliki fleksibilitas dan mampu mendorong munculnya kemandirian belajar dan motivasi untuk lebih aktif dalam belajar. Dikhawatirkan dengan kurangnya waktu pembelajaran, pembelajaran menjadi tidak efektif. Hal ini dikarenakan pembelajaran yang efektif adalah suatu pembelajaran dapat terlaksana sesuai dengan waktu yang telah ditentukan (Prasetyo, 2016: 1).

Pembelajaran lebih mudah melalui internet tanpa dibatasi oleh tempat, jarak dan waktu (Rusman, 2011: 351). Berbagai penelitian telah dilakukan untuk mengetahui bagaimana pelaksanaan PJJ baik sekolah dasar hingga perguruan tinggi dikarenakan merupakan hal baru. Simatupang dkk (2020: 199) menyatakan pembelajaran tidak hanya dilihat dari hasil belajar saja tetapi juga harus dilihat dari segi proses pembelajaran. Khusniyah \& Wana (2020: 3) mengatakan dikarenakan baru awal pelaksanaan pembelajaran online tentunya diperlukan pengkajian lebih dalam dengan melihat persepsi mahasiswa terhadap proses pembelajaran yang cenderung baru. Adanya persepsi yang kurang baik dikhawatirkan akan berdampak negatif pada keberhasilan belajar. Hasil penelitian Nugraha (2015: 2) menunjukan bahwa persepsi memberikan kontribusi yang berarti terhadap hasil belajar mahasiswa. Melalui persepsi, seseorang dapat terus mengadakan hubungan dengan 
lingkungannya yang dilakukan melelui panca inderanya (Slameto, 2010: 2). Oleh karena itu diperlukan penelitian lebih lanjut untuk mengetahui bagaimana persepsi mahasiswa hingga akhir pembelajaran sehingga dapat dijadikan evaluasi bagi pendidik dalam memperbaiki pembelajaran untuk pembelajaran berikutnya khususnya pada pembelajaran jarak jauh.

Peneliti bertujuan untuk menganalisa persepsi mahasiswa terhadap PJJ drainase secara mendalam serta mengetahui kendala pada PJJ Drainase Perkotaan. Adapun hasil yang didapatkan dapat dijadikan sebagai ukuran tingkat keberhasilan dari pembelajaran dan dapat dijadikan evaluasi bagi pendidik dalam memperbaiki kegiatan pembelajaran berikutnya.

\section{METODE}

Penelitian ini dilaksanakan pada Program Studi Pendidikan Teknik Bangunan, Fakultas Teknik, Universitas Negeri Jakarta. Penelitian ini berlangsung pada semester genap tahun akademik 2019/2020 terhitung dari bulan Mei 2020 sampai Februari 2021 secara daring dikarenakan adanya pandemi COVID-19. Subjek penelitian adalah mahasiswa semester genap tahun akademik 2019/2020 yang mengambil mata kuliah Drainase Perkotaan. Populasi dalam penelitian ini yaitu mahasiswa program studi Pendidikan Teknik Bangunan, Fakultas Teknik, Universitas Negeri Jakarta yang sedang menempuh mata kuliah Drainase Perkotaan pada semester genap tahun akademik 2019/2020. Sebanyak 20 mahasiswa telah diambil sebagai uji coba instrumen. Oleh karena itu, total populasi yang digunakan dalam penelitian ini berjumlah 47 mahasiswa. Sampel yang digunakan dalam penelitian ini adalah mahasiswa yang mengambil mata kuliah Drainase Perkotaan pada semester genap tahun akademik 2019/2020 berjumlah 47 orang.

Metode yang digunakan dalam penelitian ini adalah penelitian deskriptif kuantitatif. Uji coba instrumen ini dilakukan dengan cara memberikan instrumen kepada responden yang merupakan bagian dari sampel penelitian yaitu 20 (dua puluh) mahasiswa Pendidikan Teknik Bangunan yang mengambil mata kuliah Drainase Perkotaan pada semester genap tahun akademik 2019/2020. Uji coba instrumen dilakukan untuk memperoleh instrumen yang valid dan reliabel melalui uji validitas dan reliabilitas instrumen., uji validitas butir instrumen yang digunakan adalah menggunakan rumus product moment sebagai berikut (Arikunto, 2010: 213) dan untuk menentukan reliabilitas digunakan rumus alpha Cronbarch (Arikunto, 2010: 239).

Teknik pengumpulan data yang dilakukan dengan cara memberi seperangkat pertanyaan atau pernyataan tertulis kepada responden untuk dijawab (Sugiyono, 2015: 199) data-data dari program studi Pendidikan Teknik Bangunan berupa data nama mahasiswa dan nilai pada mata kuliah Drainase Perkotaan. Teknik analisis data dalam penelitian yang digunakan dalam penelitian ini adalah teknik statistik deskriptif.

\section{HASIL DAN PEMBAHASAN}

Data dari penelitian ini diperoleh dari hasil kuesioner yang diberikan kepada responden melalui Google Form. Responden dalam penelitian ini merupakan mahasiswa Pendidikan Teknik Bangunan angkatan 2016 dan 2017. 
Pada indikator pertama yaitu mutu pembelajaran didapatkan bahwa pengorganisasian materi pembelajaran telah dilakukan dengan cukup baik, dan ratarata mahasiswa memiliki pemahaman yang baik terhadap materi yang diberikan. Seperti halnya menurut Wortruba dan Wright dalam Hamzah B. Uno (2014: 173) bahwa pengorganisasian materi yang baik menunjukkan pembelajaran berlangsung secara efektif yaitu sesuai dengan tujuan dengan logis dan teratur. Dalam hal ini tujuan pembelajaran yaitu mahasiswa mampu memahami materi yang diberikan, adanya pengorganisasian materi yang baik maka peserta didik dapat lebih mudah dalam memahami materi. Pelaksanaan PJJ memungkinkan tidak berjalan secara sistematis dikarenakan PJJ tidak dilakukan tatap muka secara langsung karena terpisahnya pendidik dan peserta didik. Hal ini dapat menyebabkan kurangnya interaksi dalam pembelajaran yang merupakan salah satu kekurangan dari PJJ yaitu kurangnya interaksi yang dapat menghambat proses pembelajaran (Rusman, 2011: 352). PJJ pendidik dituntut untuk dapat memilih media, metode dan platform yang tepat dalam pembelajaran karena akan sangat mempengaruhi efektivitas pembelajaran (Mulyasa, 2011: 107).

Media, metode dan platform yang digunakan dapat membantu dalam meningkatkan pemahaman mahasiswa untuk mengatasi keterbatasan tatap muka secara langsung. Platform yang digunakan dalam pembelajaran adalah Google Classroom, Whatsapp dan Zoom yang dinyatakan mahasiswa mempermudah dalam memahami materi. Penggunaan variasi Platform online ini dapat disesuaikan dengan materi maupun kebutuhan pada saat pembelajaran. Pembelajaran dengan menggunakan Zoom dapat menjadi alternatif untuk pertemuan tatap muka sehingga interaksi dapat 46 berjalan dua arah, namun pembelajaran Zoom ini tidak sering dilakukan karena beberapa kendala yaitu sinyal internet dan kuota.

Indikator kedua yaitu kesesuaian tingkat pembelajaran didapatkan bahwa persepsi mahasiswa yaitu rata-rata mahasiswa merasa nyaman serta tidak terbebani dengan adanya PJJ. Dibutuhkan kemampuan adaptasi yang baik bagi mahasiswa agar dapat siap dalam menjalani pembelajaran. Hal ini sejalan dengan pernyataan Wannemacher (2006), diacu dalam Setiaji \& Dinata (2020: 65) bahwa kemampuan adaptasi yang baik sangat menentukan efektivitas penggunaan pembelajaran online. Sebagian besar mahasiswa menyatakan telah memiliki fasilitas yang mendukung serta memiliki pengetahuan yang baik tentang PJJ sehingga mahasiswa sudah siap dalam melakukan pembelajaran meskipun terkendala jarak dengan pendidik. Kesiapan mahasiswa dalam melakukan pembelajaran sangat penting baik dari dari internal maupun eksternal. Kesiapan dalam pembelajaran ini sangat diperlukan dalam merencanakan metode dan media dalam pembelajaran agar sesuai dengan karakteristik peserta didik dengan mempertimbangkan perbedaan individual. Sebagaimana Sanjaya (2012: 4142), pentingnya mempertimbangkan persiapan awal sehingga peserta didik memiliki kemampuan awal yang dibutuhkan dalam pembelajaran.

Pada indikator ketiga yaitu insentif, berdasarkan hasil data penelitian didapatkan bahwa persepsi mahasiswa terhadap pembelajaran jarak jauh Drainase Perkotaan menunjukkan bahwa meskipun pendidik sudah memberikan motivasi yang cukup 
baik, namun motivasi dari peserta didik rendah. Motivasi yang cukup rendah ini dikarenakan media serta platform yang kurang interaktif dalam pembelajaran serta baru diterapkannya PJJ pada pembelajaran. Hal ini bertentangan dengan hasil penelitian dari Fitriyani, dkk. (2020: 171) bahwa pada masa pandemik COVID-19 tidak menghalangi motivasi mahasiswa dalam melakukan kegiatan PJJ dengan rata-rata skor presentase motivasi masuk kategori sangat baik. Dalam pembelajaran pendidik sudah mengusahakan agar terus memberikan motivasi terhadap mahasiswa dengan memberikan kesempatan untuk bertanya dan berpendapat serta memberikan umpan balik terhadap tugas atau tes yang diberikan meskipun pembelajaran yang dilakukan tidak berlangsung tatap muka. Sebagian besar mahasiswa mengatakan kurang bersemangat dalam mempelajari materi dalam PJJ salah satunya dikarenakan media yang kurang menarik dalam pembelajaran. Media yang digunakan dalam PJJ Drainase berupa bahan ajar dan modul materi, dimana diperlukan penjelasan untuk mengkongkritkan bahan ajar. Diperlukannya peningkatan dan inovasi terkait media pada pembelajaran berikutnya sehingga PJJ dapat lebih menarik minat mahasiswa dalam mengikuti pembelajaran karena sesuai dengan karakterisitik mereka. Hal ini sesuai dengan pernyatan Djamarah dkk (2014: 122) proses dengan menggunakan media dapat memperjelas penyampaian materi sehingga bahan ajar bisa dikongkritkan serta merangsang kegiatan belajar. Meskipun menyatakan merasa kurang bersemangat dalam pembelajaran namun rata-rata mahasiswa mengerjakan tugas yang diberikan secara antusias dan aktif bertanya dalam pembelajaran, sejalan dengan pernyataan Firman \& Rahman (2020: 84) kelebihan pembelajaran jarak jauh yaitu mampu mendorong munculnya kemandirian dan motivasi untuk lebih aktif dalam belajar.

Indikator yang terakhir yaitu waktu, berdasarkan hasil data penelitian dapat disimpulkan bahwa persepsi mahasiswa terhadap pembelajaran jarak jauh Drainase yaitu alokasi waktu pembelajaran cukup untuk mempelajari materi baik dalam pembelajaran maupun dalam pembelajaran mandiri. Pada awal pembelajaran, mahasiswa merasa waktu dalam pembelajaran kurang, namun setelah menjalani perkuliahan selama satu semester ternyata dengan PJJ waktu yang digunakan dalam pembelajaran lebih efektif. Waktu yang cukup dalam pembelajaran dapat memungkinkan peserta didik dalam memaksimalkan penyampaian oleh dosen serta materi yang diberikan sehingga dapat mencapai tujuan pembelajaran. Hasil penelitian ini sejalan dengan pernyataan Hutami dkk (2017: 48) bahwa pemanfaatan media online dalam pembelajaran dapat mempersingkat waktu pembelajaran dimana peserta didik tidak harus menunggu guru karena media online mampu memberikan fasilitas dalam mendapatlkan informasi mengenai materi belajar. Pemilihan materi serta media online yang tepat dapat menjadikan PJJ lebih fleksibel.

$\begin{array}{clr}\begin{array}{c}\text { Fleksibilitas } \\ \text { memungkinkan }\end{array} & \text { mahasiswa dan tempat } \\ \text { dalam }\end{array}$
memperoleh informasi dari mana saja dan kapan saja sehingga dapat menyelesaikan tugas kuliah secara cepat dan mendapatkan materi dengan mudah melalui platform yang digunakan. Hal ini merupakan kelebihan dari PJJ yaitu peserta didik dan pendidik dapat berkomunikasi secara mudah melalui fasilitas internet tanpa dibatasi oleh jarak, tempat, dan waktu serta peserta didik dapat 
melakukan pembelajaran secara mandiri (Rusman, 2011: 351).

PJJ Drainase Perkotaan yang cenderung baru juga mengalami beberapa kendala dalam Pembelajaran Jarak Jauh Drainase Perkotaan yaitu kurangnya interaksi antara dosen dan mahasiswa, kurangnya sinyal dalam pembelajaran serta beberapa mahasiswa yang kurang mampu dalam belajar mandiri. Dengan kemudahan akses materi seharusnya mampu memberikan pengalaman belajar mandiri dan memanfaatkan bahan ajar yang digunakan sesuai dengan gaya belajar mahasiswa. Keterbatasan jarak antara dosen dan mahasiswa menjadikan pembelajaran berlangsung tanpa adanya tatap muka. Namun, dengan adanya bantuan aplikasi teleconverence dapat menjadikan pertemuan melalui dunia maya salah satunya yaitu dengan aplikasi Zoom. Akan tetapi karena terkendala lemahnya sinyal dibeberapa mahasiswa serta karena belum terbiasa dengan adanya sistem PJJ mata kuliah Drainase Perkotaan hanya melangsungkan pertemuan tatap muka online 2 kali dalam satu semester. Sesuai dengan hasil penelitian Jundi (2020: 16) bahwa masih adanya sebagian mahasiswa memiliki tingkat kehadiran yang kurang dalam pembelajaran jarak jauh dikarenakan faktor akses jaringan dan kuota internet oleh mahasiswa adapun beberapa mahasiswa dapat masuk kedalam meeting perkuliahan namun tidak dapat menampilkan video dan audio karena jaringan tidak stabil.

Adapun media yang digunakan berupa E-modul, media ini kurang dapat mengkongkritkan materi materi khususnya materi yang berupa prinsip, prosedur dan keterampilan dimana pada mata kuliah Drainase Perkotaan terdapat materi dasar dasar perancangan, prosedur perancangan hingga melakukan perhitungan perancangan drainase yang memerlukan penjabaran lebih detail. Dalam pembelajaran jarak jauh karena pemberian materi tidak diberikan secara langsung maka menuntut mahasiswa untuk melakukan pembelajaran secara mandiri tentang materi yang beum dipahami baik dengan bertanya kepada dosen pengampu maupun melakukan pencarian materi baik melalui internet maupun sumber sumber belajar yang telah diberikan oleh dosen. Mahasiswa menjalani proses pembelajaran di perguruan tinggi atau tahapan tertinggi dalam menuntut ilmu. Seyogyanya menuntut ilmu bagi seorang mahasiswa menuntut untuk berfikir kritis. Kemampuan mahasiswa dalam pembelajaran mandiri seharusnya tidak menjadi kendala dalam pembelajaran jarak jauh. Pada pembelajaran selanjutnya diharapkan pendidik lebih memperbanyak variasi media pembelajaran serta bahan ajar yang lebih inovatif seperti video animasi maupun video tutorial untuk menggambarkan materi Drainase Perkotaan serta pengaplikasiannya dalam kehidupan sehari hari. Pembelajaran lebih interaktif dengan diperbanyak diskusi serta latihan pada tiap pertemuan serta lebih sering diadakan pertemuan virtual agar dapat menyamakan persepsi antar peserta didik. Adapun menurut hasil penelitian Khusniyah \& Wana (2020: 8) penambahan video tutor pembelajaran sehingga dosen bisa menyampaikan materi secara lisan sehingga menambah interaksi dalam pembelajaran. Pemaparan materi secara lisan dapat memudahkan mahasiswa dalam bertanya secara langsung serta penjelasan yang lebih mudah untuk dipahami mahasiswa. Sanjaya (2012:41) mengemukakan bahwa penggunaan metode dan media yang tepat dalam pembelajaran harus disesuaikan 
dengan minat dan kebutuhan sehingga meningkatkan motivasi siswa dalam pembelajaran. Media dan metode yang digunakan harus interaktif dan sesuai dengan materi pembelajaran terkhusus pada pembelajaran dengan sistem jarak jauh. Diperlukannya beberapa perbaikan dari hasil evaluasi PJJ agar nantinya dapat memperbaiki pembelajaran selanjutnya khususnya dalam mengatasi kendalakendala yang ada dalam PJJ. Sejalan dengan hasil penelitian Saifuddin (2017: 108) yang juga mengatakan diperlukannya pengembangan pembelajaran online dikombinasikan dengan model pembelajaran serta bahan ajar agar pembelajaran online dapat lebih maksimal.

\section{SIMPULAN}

Persepsi mahasiswa terhadap pembelajaran jarak jauh pada mata kuliah Drainase Perkotaan semester genap Tahun Akademik 2020 dapat dikatakan cukup baik. Persepsi mahasiswa terhadap mutu pembelajaran sebesar 42,6\% masuk kategori cukup baik. Pengorganisasian materi, media metode, platform yang digunakan telah sesuai dengan tujuan pembelajaran meskipun pembelajaran belum dilakukan secara sistematis. Persepsi mahasiswa terhadap kesesuaian tingkat pembelajaran sebesar 38,3\% masuk kategori baik. Mahasiswa telah memiliki fasilitas serta pengetahuan tentang PJJ meskipun dengan adanya PJJ membuat mahasiswa merasa nyaman dan termotivasi dalam pembelajaran. Persepsi Mahasiswa terhadap insentif pembelajaran sebesar 36,2\% dengan kategori cukup baik. Pendidik sudah memberikan sikap positif berupa kesempatan bertanya serta pemberian umpan balik dalam pembelajaran.
Mahasiswa merasa bersemangat dalam bertanya dan mengerjakan tugas, namun metode yang digunakan tidak menjadikan bersemangat dalam mempelajari materi. Persepsi Mahasiswa terhadap waktu sebesar 46,8\% mahasiswa dengan kategori baik, alokasi waktu yang digunakan cukup dalam pembelajaran baik dalam proses belajar mengajar maupun dalam mengerjakan tugas.

$$
\text { Kendala dalam PJJ Drainase }
$$

Perkotaan adalah kurangnya interaksi dalam pembelajaran, sinyal yang kurang mendukung dalam mengakses pembelajaran, kurangnya pemahaman materi dikarenakan pembelajaran menjadi tidak seintens pembelajaran tatap muka serta tatap muka daring yang kurang menyebabkan beberapa materi sulit untuk dipahami serta diperlukannya variasi media dalam pembelajaran.

Berdasarkan penelitian yang telah dilakukan, maka terdapat beberapa saran diantaranya adalah sebagai berikut 1) Bagi mahasiswa diharuskan mempunyai inisiatif dalam belajar mandiri serta penggunaan waktu dan sumber belajar yang efektif dan efisien sehingga mampu memahami materi secara maksimal meskipun pembelajaran dilakukan secara jarak jauh. 2) Bagi para peneliti selanjutnya dapat dapat melakukan penelitian secara lebih luas dan mendalam tidak hanya terbatas pada persepsi mahasiswa terhadap pembelajaran. Dilakukannya pengembangan serta efektivitas terhadap media serta bahan ajar dalam pembelajaran jarak jauh khususnya pada mata kuliah Drainase Perkotaan. 3) Bagi dosen diharapkan memaksimalkan penggunaan LMS atau aplikasi video converence oleh pendidik disesuaikan dengan materi pembelajaran sehingga interaksi dalam pembelajaran akan berjalan efektif serta dapat mencapai tujuan 
pembelajaran yang diinginkan.

Diperlukannya pengembangan terhadap media maupun bahan ajar yang dapat memudahkan mahasiswa dalam belajar mandiri.

\section{DAFTAR RUJUKAN}

Bustomi, A. (2020). Implikasi COVID 19 Terhadap Pembelajaran di Perguruan Tinggi. Jurnal Tawadhu, 4(1), 10071017.

Djamarah, Bahri, S., \& Zain, A. (2014). Psikologi Belajar.

Firman, \& Rahman, S. R. (2020). Pembelajaran Online di Tengah Pandemi Covid-19. Indonesian Journal of Educational Science (IJES), 2(2), 81-89.

Fitriyani, Y., Fauzi, I., \& Sari, M. Z. (2020). Motivasi Belajar Mahasiswa Pada Pembelajaran Daring Selama Pandemik Covid-19. Jurnal Kependidikan: Jurnal Hasil Penelitian Dan Kajian Kepustakaan Di Bidang Pendidikan, Pengajaran Dan Pembelajaran, 6(2), 165-175. https://doi.org/https://doi.org/10.333 94/jk.v6i2.2654

Hutami, R. A., Sudiyanto, \& Ivada, E. (2017). Keefektifan Model ELearning Pada Pembelajaran Akuntansi di SMA Negeri 1. Jurnal "Tata Arta" UNS, 3(3), 22-31.

Jundi, M. (2020). Persepsi Mahasiswa Terhadap Perkuliahan Nahwu dengan Sistem Daring. Jurnal Budaya, Bahasa Dan Sastra Arab,
17(2).

https://doi.org/https://doi.org/10.210 09/almakrifah.17.02.01

Khusniyah, T. W., \& Wana, P. R. (2020). Persepsi Mahasiswa PGSD pada Inovasi Pembelajaran Berbasis ELearning. Wahana Sekolah Dasar, 28(1), 1-10.

Mulyasa. (2011). Menjadi Guru Profesional. Bandung: PT. Remaja Rosdakarya.

Nugraha, U. (2015). Hubungan Persepsi, Sikap Dan Motivasi Belajar Terhadap Hasil Belajar Pada Mahasiswa Pendidikan Olahraga Dan Kesehatan Universitas Jambi. Jurnal Cerdas Sifa, 1(1).

Prasetyo, N. Y. (2016). Persepsi Mahasiswa Terhadap Efektifitas Pembelajaran dengan Sistem Blok Matakuliah Praktikum pada Jurusan Teknik Mesin Fakultas Teknik. Jurnal Teknik Mesin, 24(2).

Rusman. (2011). Model-model Pembelajaran; Mengembangkan Profesionalisme Guru. Jakarta: PT RajaGrafindo Persada.

Saifuddin, M. (2017). E-Learning dalam Persepsi Mahasiswa. Jurnal Varidika, 29 (2).

Sanjaya, W. (2012). Media Komunikasi Pembelajaran. Jakarta: Prenadamedia Group.

Setiaji, B., \& Dinata, P. A. C. (2020). Analisis kesiapan mahasiswa jurusan pendidikan fisika menggunakan e- 
Persepsi Mahasiswa... (Prisma/ hal. 45-53)

learning dalam situasi pandemi

Covid-19. Jurnal Inovasi Pendidikan IPA, 6(1), 59-70. Retrieved from https://doi.org/10.21831/jipi.v6i1.31 $\underline{562}$

Simatupang, N. I., sia Sitohang, S. R. I., Situmorang, A. P., \& Simatupang, I. M. (2020). Efektivitas Pelaksanaan Pengajaran Online Pada Masa Pandemi COVID-19 dengan Metode Survey Sederhana. Jurnal Dinamika Pendidikan, 13

https://doi.org/DOI

10.33541/jdp.v13i2.1754

Slameto. (2010). Belajar dan Faktor-faktor yang Mempengaruhinya. Jakarta: Rineka Cipta.

Uno, H. B. (2014). Belajar dengan Pendekatan PAILKEM. Jakarta: Bumi Aksara. 